\title{
Gonadotropin regulation and role of ovarian osteopontin in the periovulatory period
}

\author{
Yoshimitsu Kuwabara', Akira Katayama², Ryoko Tomiyama', Hu Piao', \\ Sachiko Kurihara, ${ }^{1,2}$, Shuichi Ono', Katsuya Mine', Shigeo Akira', Hideo Orimo ${ }^{2}$ \\ and Toshiyuki Takeshita'
}

Departments of ${ }^{1}$ Obstetrics and Gynecology, and ${ }^{2}$ Biochemistry and Molecular Biology, Nippon Medical School, 1-1-5, Sendagi, Bunkyo-ku, Tokyo 113-8603, Japan

\begin{abstract}
Osteopontin (OPN), a secreted glycoprotein, has multiple physiological functions. This study investigated the regulation and roles of OPN in the mouse ovary during the periovulatory stages. Immature female mice were treated with pregnant mare serum gonadotropin (PMSG) and human chorionic gonadotropin (hCG) to simulate follicle maturation and ovulation. In situ hybridization and real-time RT-PCR were performed to assess expression of Opn in the periovulatory ovary. Granulosa cells (GCs) from PMSGprimed immature mice were cultured with or without hCG in the presence or absence of OPN, and effects on expression of Opn, progesterone synthesis, and vascular endothelial growth factor (VEGF) signaling were assessed by real-time RT-PCR, ELISA, and western blotting analysis. Opn transcripts were significantly upregulated $3 \mathrm{~h}$ after $\mathrm{hCG}$ treatment, followed by a peak at $16 \mathrm{~h}$, and the transcripts localized to GCs. Incubation with hCG significantly increased quantities of Opn transcripts in GCs and OPN levels in the culture medium at 12 and $24 \mathrm{~h}$. Furthermore, OPN treatment caused a significant increase in the levels of Star protein, P 450 cholesterol side-chain cleavage enzyme ( $0450 \mathrm{scc}$ ), 3-betahydroxysteroid dehydrogenase $(H s d 3 b)$, and progesterone in the culture medium.

OPN treatment promoted Vegf expression in GCs, which was significantly suppressed by a phosphoinositide 3-kinase (PI3K) inhibitor. In addition, OPN treatment stimulated phosphorylation of AKT, a downstream PI3K signaling molecule. In conclusion, expression of Opn was upregulated in mouse ovarian GCs in response to a gonadotropin surge through epidermal growth factor receptor signaling, which enhances progesterone synthesis and Vegf expression during the early-luteal phase.
\end{abstract}

Correspondence should be addressed to $Y$ Kuwabara Email

kuwa@nms.ac.jp

\author{
Key Words \\ - gonadotropin \\ - epidermal growth factor \\ - progesterone \\ - corpus luteum
}

Journal of Endocrinology (2015) 224, 49-59

\section{Introduction}

In the periovulatory period, multiple local factors secreted by different ovarian cell compartments mediate or modulate the actions of gonadotropin via the paracrine and/or autocrine pathways (Richards 1994, Christenson \& Stouffer 1997). Recently, we have reported that expression of chemokine CCL11 is upregulated transiently in the ovarian theca-interstitial layer and involved in follicular vascular formation (Kuwabara et al. 2012). Identification and characterization of these factors regulated during the periovulatory stages provides understanding of 
physiological processes such as follicle transformation to the corpus luteum and oocyte maturation and release.

Osteopontin (OPN) is a secreted glycosylated phosphoprotein, originally isolated from the bone matrix (Giachelli et al. 1991). OPN is distributed in a wide variety of tissues, including kidney and epithelial cells of the gastrointestinal tract, gall bladder, pancreas, urinary and reproductive tracts, lungs, breasts, salivary and sweat glands, inner ear, brain, placenta, and arteries (Butler 1989, Giachelli et al. 1991, Brown et al. 1992). OPN is also present in body fluids such as milk and urine (Denhardt \& Guo 1993). A diverse distribution pattern indicates that OPN is multifunctional and involved in angiogenesis and tissue remodeling (Ingber 1992, Giachelli et al. 1995, Liaw et al. 1995a,b, Corjay et al. 1999). OPN promotes cell adhesion, signaling, and migration in the immune response and in neoplasia (Denhardt \& Guo 1993, Sodek et al. 2000).

In reproductive tissues of females, OPN was detected in the human ovary (Brown et al. 1992), human and ovine endometrium (Brown et al. 1992, Johnson et al. 1999), and oviduct (Gabler et al. 2003). Furthermore, some reports have described expression of $O P N$ in ovaries during the periovulatory and luteal phases. According to the results of a microarray analysis of granulosa cells (GCs) from pregnant mare serum gonadotropin (PMSG)-primed immature mice, Opn is one of the 419 genes significantly upregulated by human chorionic gonadotropin (hCG) stimulation (McRae et al. 2005). Furthermore, a novel ovarian protein, sharing sequence similarity with mammalian and chicken OPNs, was detected in trout periovulatory ovary (Bobe \& Goetz 2001). OPN transcripts were also detected in bovine ovarian follicles and corpus lutea (Brunswig-Spickenheier \& Mukhopadhyay 2003). Recently, results of a detailed study have indicated that OPN is localized in bovine luteal cells during the luteal phase of the estrous cycle and is involved in the development and regression of the corpus luteum (Poole et al. 2013). To our knowledge, normal OPN expression in follicular or luteal cells in adult animals has not been reported, except for expression in the bovine ovary.

Hence, ovarian OPN expression has been demonstrated in some species; however, the regulation, localization, and functions of OPN in the ovary, especially in the periovulatory phase, have yet to be revealed.

Using a PCR array analysis of growth factor transcripts expressed in the mouse ovary, we identified a marked increase in $O p n$ transcripts after preovulatory stimulation with hCG. Based on the results, we sought to clarify the detailed localization, regulatory mechanism, and physiological roles of OPN in the periovulatory ovary using an immature mouse ovarian stimulation model. In this study, we provide experimental evidence that Opn expression is markedly upregulated in mouse ovarian GCs in response to a gonadotropin surge through epidermal growth factor receptor (EGFR) signaling, which is involved in corpus luteum formation and function during the early-luteal phase.

\section{Materials and methods}

\section{Animals}

Immature female B6D2F1 (21 days old) and adult (16 weeks old) mice were obtained from Charles River Laboratories Japan (Kanagawa, Japan). Immature female mice were treated with 7.5 IU of PMSG (ASKA, Tokyo, Japan) administered by s.c. injection, followed by treatment with $10 \mathrm{IU}$ of hCG (ASKA) by i.p. injection $48 \mathrm{~h}$ later to stimulate follicle maturation and ovulation respectively. The Laboratory Animals Ethics Committee of Nippon Medical School reviewed and approved all experimental procedures.

\section{PCR array analyses}

Mice $(n=12)$ at 21 days of age received injections of PMSG preparation (7.5 IU/animal), containing folliclestimulating hormone and luteinizing hormone (LH) to stimulate follicular growth. Forty-eight hours later, some animals were treated with an hCG preparation (10 IU/animal, administered i.p.) with LH activity.

The ovaries were dissected from the killed animals $48 \mathrm{~h}$ after PMSG treatment ( $n=6$ per group) and $6 \mathrm{~h}$ after hCG treatment ( $n=6$ per group) for total RNA extraction using an RNeasy Mini Kit (Qiagen Sciences). Equal amounts of total RNA from each sample were reverse-transcribed to cDNA using a Superscript FirstStrand Synthesis Kit (Invitrogen) and pooled for subsequent PCR array analyses. The expression levels of molecules related to growth factors were evaluated using the RT2 Profiler PCR Array System (SABiosciences, Frederick, MD, USA) and an ABI Prism 7500 Sequence Detection System (Applied Biosystems). The mRNA levels were normalized to the levels of $\beta$-actin mRNA using the following equation: relative mRNA expression $=2^{-(C t \text { of targeting molecule }-C t \text { of } \beta \text {-actin })}(\mathrm{Ct}$, threshold cycle). The change in the expression level was assessed by dividing the relative expression values for hCG-treated animals by those for PMSG-primed animals.

Published by Bioscientifica Ltd. 


\section{Isolation of ovarian compartments for RT-PCR}

Immature female mice were treated with PMSG and hCG as described previously and dissected 6 and $16 \mathrm{~h}$ after hCG treatment. Thereafter, GCs were isolated from the whole ovary by puncture of preovulatory follicles with needles and fine forceps under a stereomicroscope. GCs and the residual ovaries (RO) were snap-frozen and stored at $-70{ }^{\circ} \mathrm{C}$ for subsequent analysis. RO represents the tissue remaining after GC collection, heterogeneous tissue comprises theca-interstitial and stromal cells, as well as remaining GCs.

\section{Relative quantification of gene expression}

To assess mRNA expression, pre-designed gene-specific primer pairs and probes were selected for the following target genes: Opn (ID Mm00436767_m1), Star protein (Mm00441558_m1), P450 cholesterol side-chain cleavage enzyme (p450scc) (Mm00490735_m1), 3-betahydroxysteroid dehydrogenase isomerase $(\mathrm{Hsd} 3 \mathrm{~b})$ (Mm00476184_g1), vascular endothelial growth factor (Vegf) (Mm0128-1449_m1), and an endogenous control, $\beta$-actin (Actb) (Mm00607939_s1) within a list of predesigned assays (Assays-on-Demand; Applied Biosystems). The whole ovaries or cultured GCs were collected for total RNA extraction after treatment of immature mice with gonadotropin. RNA was extracted using an RNeasy Mini Kit (Qiagen Sciences). Total RNA $(2 \mu \mathrm{g})$ was reversetranscribed for subsequent PCR analysis. Real-time PCR was performed in a final reaction volume of $20 \mu \mathrm{l}$, containing $10 \mu \mathrm{l}$ of $2 \times$ TaqMan Universal PCR Master Mix (Applied Biosystems), $1 \mu$ of $20 \times$ primer/probe assay mix (Applied Biosystems), and $5 \mu \mathrm{l}$ of DNA template. PCR was performed in MicroAmp optical 96-well plates with optical adhesive covers (Applied Biosystems). Amplification and detection were performed with an ABI Prism 7500 Sequence Detection System (Applied Biosystems). The amplification conditions were $2 \mathrm{~min}$ at $50{ }^{\circ} \mathrm{C}$ for AmpErase uracil- $N$-glycosylase activity, $10 \mathrm{~min}$ at $95^{\circ} \mathrm{C}$ for AmpliTaq Gold activation, 50 cycles of $15 \mathrm{~s}$ at $92{ }^{\circ} \mathrm{C}$ for denaturation, and $1.5 \mathrm{~min}$ at $60^{\circ} \mathrm{C}$ for annealing and extension. After amplification, the fluorescence end-point was detected at $60^{\circ} \mathrm{C}$. The fluorescence data were analyzed with Allelic Discrimination Software for the ABI Prism 7500 instrument. The samples were assayed in duplicate for each gene, and the mean expression was used during subsequent analysis. Relative expression was calculated using the comparative $\Delta \Delta C$ t method (Applied Biosystems 1997).

\section{In situ hybridization analyses}

To localize Opn in the ovary, paraffin-embedded blocks and ovary sections from PMSG-primed mice before and after hCG treatment were obtained for in situ hybridization (ISH) from Genostaff Co. Ltd (Tokyo, Japan). The mouse ovaries were dissected, fixed with Tissue Fixative (Genostaff Co. Ltd), embedded in paraffin according to proprietary procedures, and sectioned at $6 \mu \mathrm{m}$. For ISH, tissue sections were deparaffinized with xylene and rehydrated with an ethanol series and PBS. The sections were fixed with 4\% paraformaldehyde in PBS for 15 min and then washed with PBS. The sections were treated with $8 \mu \mathrm{g} / \mathrm{ml}$ proteinase $\mathrm{K}$ in PBS for $30 \mathrm{~min}$ at $37^{\circ} \mathrm{C}$, washed with PBS, re-fixed with $4 \%$ paraformaldehyde in PBS, washed again with PBS, and placed in $0.2 \mathrm{~mol} / \mathrm{l}$ $\mathrm{HCl}$ for $10 \mathrm{~min}$. After washing with PBS, the sections were acetylated by incubation for $10 \mathrm{~min}$ in $0.1 \mathrm{~mol} / 1$ triethanolamine- $\mathrm{HCl} \quad(\mathrm{pH} \quad 8.0)$ with $0.25 \%$ acetic anhydride. After washing with PBS, the sections were dehydrated through a series of ethanol solution. Hybridization was performed at $60{ }^{\circ} \mathrm{C}$ for $16 \mathrm{~h}$ with probes at a concentration of $300 \mathrm{ng} / \mathrm{ml}$ in Probe Diluent-1 (Genostaff Co. Ltd). After hybridization, the sections were washed with $5 \times$ HybriWash (Genostaff Co. Ltd, $5 \times$ saline sodium citrate) at $50{ }^{\circ} \mathrm{C}$ for $20 \mathrm{~min}$ and then with $50 \%$ formamide with $2 \times$ HybriWash at $50{ }^{\circ} \mathrm{C}$ for $20 \mathrm{~min}$, followed by RNase treatment for $30 \mathrm{~min}$ at $37^{\circ} \mathrm{C}$ with $50 \mu \mathrm{g} / \mathrm{ml}$ RNaseA in $10 \mathrm{mmol} / \mathrm{l}$ Tris-HCl (pH 8.0) with $1 \mathrm{~mol} / \mathrm{l} \mathrm{NaCl}$ and $1 \mathrm{mmol} / 1$ EDTA. Then, the sections were washed twice with $2 \times$ HybriWash at $50^{\circ} \mathrm{C}$ for $20 \mathrm{~min}$, twice with $0.2 \times$ HybriWash at $50^{\circ} \mathrm{C}$ for $20 \mathrm{~min}$, and once with Tris-buffered saline with Tween (TBST), which contains $0.1 \%$ Tween 20. After treatment with $0.5 \%$ blocking reagent (Roche) in TBST for $30 \mathrm{~min}$, the sections were incubated for $2 \mathrm{~h}$ at room temperature with anti-digoxigenin alkaline phosphatase conjugate (Roche) diluted 1:1000 with TBST. The sections were washed twice with TBST and then incubated in $100 \mathrm{mmol} / \mathrm{l} \mathrm{NaCl}, 50 \mathrm{mmol} / \mathrm{l} \mathrm{MgCl}_{2}, 0.1 \%$ Tween 20, and $100 \mathrm{mmol} / \mathrm{l}$ Tris- $\mathrm{HCl}$ (pH 9.5). Coloring reactions were carried out overnight in nitro-blue tetrazolium chloride/5-bromo-4-chloro-3'-indolyphosphate p-toluidine salt (NBT/BCIP) solution (Sigma), and then samples were washed with PBS. The sections were counterstained with Kernechtrot Stain Solution (Mutoh Chemical Co., Tokyo, Japan), dehydrated, and mounted with Malinol (Mutoh Chemical Co.). The probe sequence used for the assay corresponded to the complementary sequence of Opn nucleotides 548-906.

Published by Bioscientifica Ltd 


\section{GC preparation and culture}

The ovaries were collected from PMSG-primed immature mice and punctured in L-15 Leibovitz medium (Invitrogen). Ovarian debris, oocytes, and small follicles were removed, and the remaining medium containing GCs was collected after low-speed centrifugation at $500 \boldsymbol{g}$ for $10 \mathrm{~min}$. GCs were dispersed by repeated washing and were resuspended into culture medium (McCoy's 5a supplemented with $10^{-7} \mathrm{~mol} / \mathrm{l}$ androstenedione, $2 \mathrm{mmol} / \mathrm{l}$ L-glutamine, 100 units $/ \mathrm{ml}$ penicillin, and $100 \mu \mathrm{g} / \mathrm{ml}$ streptomycin). For gene expression analyses, GCs were cultured at a density of 250000 cells/well in a four-well plate $(15.5 \mathrm{~mm}$ in diameter) with hCG $(1 \mathrm{IU} / \mathrm{ml})$ with or without mouse recombinant OPN $(0.2 \mu \mathrm{mol} / \mathrm{l} ; \mathrm{O} 2260$, Sigma $)$. The OPN dose for GC treatment was determined based on the reported $\mathrm{EC}_{50}$ in a cell migration assay using vascular smooth muscle cells to evaluate the effect of OPN via an integrin receptor (Yue et al. 1994). GCs were also treated with hCG (1 IU/ml), EGF (5 ng/ml; E9644, Sigma), epiregulin (Ereg; $5 \mathrm{ng} / \mathrm{ml}$; 1068-EP, R\&D, Minneapolis, MN, USA), or amphiregulin (Areg; $50 \mathrm{ng} / \mathrm{ml} ; 989-A R, R \& D$ ) with or without AG1478 (50 or $150 \mathrm{nmol} / \mathrm{l}$; Cell Signaling Technology, Waltham, MA, USA), which is a tyrosine kinase inhibitor specifically selective for EGFR. Furthermore, to assess the OPN-induced intracellular signaling, GCs were pretreated for $1 \mathrm{~h}$ with LY294002 (Cell Signaling Technology), a phosphoinositide 3-kinase (PI3K) inhibitor (50 $\mu \mathrm{mol} / \mathrm{l})$, and/or PD980592 (100 $\mu \mathrm{mol} / \mathrm{l}$; Cell Signaling Technology), an ERK inhibitor, and cells were incubated with OPN in the culture medium containing hCG. For RNA isolation, incubated GCs were snap-frozen and stored at $-80^{\circ} \mathrm{C}$. For western blotting analyses, GCs were cultured at a density of 1000000 cells/well in a six-well plate $(34.8 \mathrm{~mm}$ in diameter) with hCG $(1 \mathrm{IU} / \mathrm{ml})$ for $12 \mathrm{~h}$. After changing the medium, GCs were incubated with or without OPN $(0.2 \mu \mathrm{mol} / \mathrm{l})$ for $15 \mathrm{~min}$. The cells were scraped into ice-cold PBS and transferred to a microfuge tube followed by centrifugation at $10000 \boldsymbol{g}$ for $10 \mathrm{~min}$. After aspiration of PBS, cells were lysed by adding $100 \mu \mathrm{l}$ of $1 \times$ SDS sample buffer $(62.5 \mathrm{mM}$ Tris, $\mathrm{pH} 6.8,2 \%$ SDS, $10 \%$ glycerol, $0.1 \mathrm{~mol} / 1$ dithiothreitol, and $0.01 \%$ bromophenol blue) and sonicated for 10-15 s. The lysate was stored at $-80{ }^{\circ} \mathrm{C}$ until analysis and heated to $95-100{ }^{\circ} \mathrm{C}$ for $5 \mathrm{~min}$ before the assay.

\section{Plasma OPN assay}

PMSG-primed mice were decapitated at 0, 12, 16, and $24 \mathrm{~h}$ after hCG treatment, and blood was collected into the tubes containing EDTA-2Na $(1 \mathrm{mg} / \mathrm{ml}$ blood) followed by centrifugation at $3000 \mathrm{~g}$ for $20 \mathrm{~min}$ at $4{ }^{\circ} \mathrm{C}$. Plasma aliquots were transferred into $1.5 \mathrm{ml}$ Eppendorf tubes and stored at $-80^{\circ} \mathrm{C}$ for later measurement. Plasma OPN concentrations were measured by ELISA.

\section{ELISA}

To analyze progesterone and OPN concentrations, mouse plasma or the GC culture supernatant was examined with the commercial ELISA Kits. OPN levels were assayed with a Mouse OPN ELISA Kit (IBL, Minneapolis, MN, USA; cat \#IB3054) according to the manufacturer's instructions. Progesterone levels were determined with a Progesterone ELISA Kit (Cayman Chemical Company, Ann Arbor, MI, USA; cat \#582601) according to the manufacturer's instructions.

\section{Western blotting analysis}

To analyze AKT phosphorylation, $10 \mu \mathrm{g}$ of control or OPN-treated cell lysate was separated on a $4-20 \%$ SDS-polyacrylamide gel (4-20\% Mini-PROTEAN TGX Gel; Bio-Rad) and transferred electrophoretically to a PVDF membrane (Trans-Blot Turbo Mini PVDF Transfer Packs; Bio-Rad). The membrane was blocked in a blocking solution (PVDF Blocking Reagent for Can Get Signal; TOYOBO, Osaka, Japan) and then incubated overnight with a primary antibody. Primary antibodies (1:2000 dilution, Can Get SignalR Immunoreaction Enhancer Solution 1; TOYOBO) were the following: rabbit antip-AKT (phospho-Akt (Ser ${ }^{473}$ ), 4060; CST), rabbit antip-AKT $\left(\right.$ Thr $^{308}, 2965$; CST), and rabbit anti-AKT (4691; CST). The unbound primary antibody was removed by washing the membrane at $25^{\circ} \mathrm{C}$ with Tris-buffered solution $(20 \mathrm{mmol} / \mathrm{l}$ Tris-HCl of $\mathrm{pH} 7.6,137 \mathrm{mmol} / \mathrm{l}$ $\mathrm{NaCl}, 0.1 \%$ Tween 20), followed by incubation with secondary antibody (goat anti-rabbit IgG-HRP; GE Healthcare, Little Chalfont, England) diluted 1:2000 in Can Get SignalR Immunoreaction Enhancer Solution 2 (TOYOBO). The protein was then visualized using ECL Prime Western Blotting Detection Reagents (GE Healthcare) and imaged using a LAS-4000 Luminescent Image Analyzer (FujiFilm Co., Tokyo, Japan). Densitometric analysis was performed using Multi Gauge version 3.1 (FujiFilm Co.), and p-AKT levels were normalized to mean total AKT levels.

\section{Statistical analyses}

All data are presented as mean \pm s.e.m. of at least three independent experiments. Each assay was performed

Published by Bioscientifica Ltd. 
using materials from different mice or GCs individually incubated under specific conditions. The results were analyzed by one-way ANOVA followed by $t$-test with Bonferroni's correction, and $P<0.05$ was considered statistically significant.

\section{Results}

\section{Evaluation of ovarian Opn transcripts and plasma OPN levels in mice during the periovulatory period}

By using PCR array analyses targeting growth-factorrelated molecules of mouse ovarian transcripts, we discovered a marked increase in Opn transcripts after hCG stimulation (Supplementary Table 1, see section on supplementary data given at the end of this article). To analyze the regulation in detail, we performed real-time RT-PCR of ovarian Opn transcripts in mice treated with PMSG and receiving an ovulatory dose of hCG $(1.0 \mathrm{IU} / \mathrm{ml})$ by injection $48 \mathrm{~h}$ later. Treatment with hCG increased $O p n$ levels within $3 \mathrm{~h}(n=3, P<0.0005)$, followed by a peak at $16 \mathrm{~h}(n=3, P<0.0001$; Fig. 1A). Using GCs and RO from the ovaries primed with PMSG for $48 \mathrm{~h}$ and subsequently treated with hCG for 6 or $16 \mathrm{~h}$, real-time RT-PCR was carried out to examine Opn expression. Expression of Opn increased predominantly in the GCs compared with that in the RO at both 6 and $16 \mathrm{~h}$ after hCG treatment $(n=3$; $6 \mathrm{~h}, P<0.005$ and $16 \mathrm{~h}, P<0.00005$; Fig. 1B), indicating that GCs represent a cell type that prominently expresses $O p n$ in response to a gonadotropin surge. We also examined the mouse plasma Opn levels during gonadotropin treatment. PMSG-primed mice were treated with hCG and killed 0, 12, 16, and 24 h later. Basal plasma $O p n$ levels were $3701-4205 \mathrm{ng} / \mathrm{ml}$ with a mean of $3987.7 \mathrm{ng} / \mathrm{ml}$ (s.D. $\pm 258.9 \mathrm{ng} / \mathrm{ml}$ ). Treatment with hCG significantly increased plasma $O p n$ levels at $16 \mathrm{~h}(n=4,0 \mathrm{~h}$ versus $16 \mathrm{~h}, P<0.01)$ and $24 \mathrm{~h}(n=4,0 \mathrm{~h}$ versus $24 \mathrm{~h}, P<0.05)$ (Fig. 1C), the kinetics of which are similar to those observed for ovarian Opn transcripts.

\section{Opn localization in mouse ovaries during the periovulatory period}

We further confirmed the localization of Opn by ISH analyses. Opn was expressed in cumulus cells of preovulatory follicles $10 \mathrm{~h}$ after hCG treatment (Fig. 2A). In addition, $O p n$ transcripts were expressed markedly in preovulatory follicle GCs $12 \mathrm{~h}$ after hCG treatment (Fig. 2B). In contrast, Opn transcripts were distributed sparsely in the ovaries dissected from 16-week-old adult mice (Fig. 2C), which may reflect the transient pattern of expression of Opn in the ovarian cycle. Further evaluations using adult mice at identified estrous stages are required to clarify the normal expression pattern of Opn during the ovarian cycle.
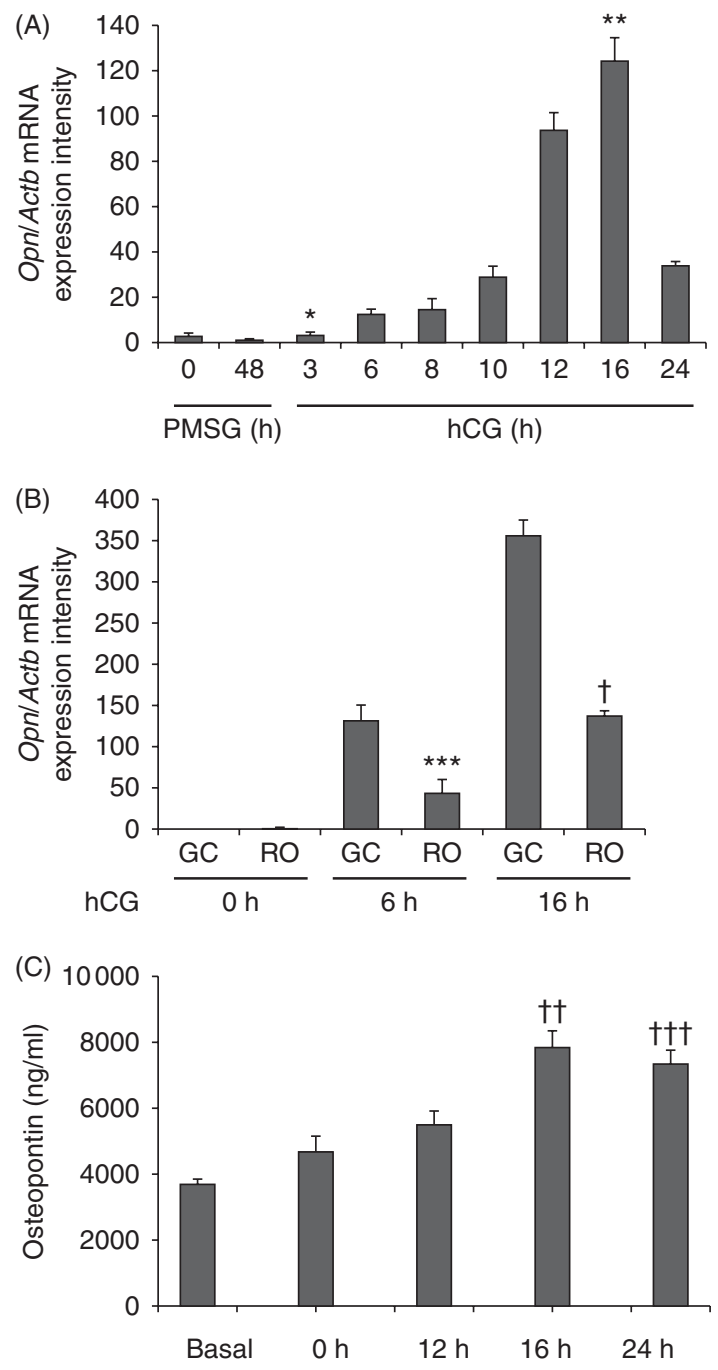

\section{Figure 1}

Evaluation of ovarian Opn transcripts and plasma OPN levels in mice during the periovulatory period. (A) Real-time PCR detection of Opn transcripts in mouse ovaries during the periovulatory period. Sequential changes in Opn expression levels are shown as fold increases relative to expression levels in pregnant mare serum gonadotropin (PMSG)-primed ovaries ( $0 \mathrm{~h}$ after human chorionic gonadotropin (hCG) treatment). PMSG-primed versus $3 \mathrm{~h}$ after hCG: ${ }^{*} P<0.0005$ and PMSG-primed vs $16 \mathrm{~h}$ after hCG: $* * P<0.0001$. (B) Realtime RT-PCR analyses of Opn transcripts in isolated ovarian compartments (GC, granulosa cells; RO, residual ovaries) obtained from PMSG-primed ovaries $(0,6$, and $16 \mathrm{~h}$ after hCG treatment). Opn levels in each ovarian compartment are shown as fold increases relative to those in GCs $0 \mathrm{~h}$ after hCG treatment. GC versus RO, $6 \mathrm{~h}:{ }^{* *} P<0.005$ and $16 \mathrm{h:}{ }^{\dagger} P<0.00005$. (C) Plasma OPN levels during gonadotropin treatment. PMSG-primed mice were treated with hCG and killed $0,12,16$, and $24 \mathrm{~h}$ later. $0 \mathrm{~h}$ versus $16 \mathrm{~h}$ : ${ }^{\dagger \dagger} P<0.01$ and $0 \mathrm{~h}$ versus $24 \mathrm{~h}:{ }^{\dagger+\dagger} P<0.05$. All $O p n$ transcript values were normalized based on $\beta$-actin levels. All data are presented as mean \pm s.E.M. for three independent experiments using material from different mice. 


\section{Expression and regulation of Opn in cultured GCs}

To determine whether the in vivo induction of Opn expression can be mimicked in vitro by activating the LH receptor, immature female mice were treated with PMSG, and GCs were isolated from preovulatory ovaries that were obtained $48 \mathrm{~h}$ after treatment. GCs were cultured in the absence or presence of a luteinizing dose of hCG $(1.0 \mathrm{IU} / \mathrm{ml})$. Real-time RT-PCR revealed that incubation with hCG significantly induced the expression of $O p n$ in cultured GCs at $12 \mathrm{~h}(n=3, P<0.0005)$ and $24 \mathrm{~h}(n=3$,
$P<0.00005$; Fig. 3A). To analyze the levels of OPN protein secretion, OPN from GC culture supernatant was measured by ELISA. Incubation with $1 \mathrm{U} / \mathrm{ml}$ hCG induced a significant increase in OPN protein levels in the culture media of PMSG-primed GCs at $12 \mathrm{~h}(n=3, P<0.0005)$ and at $24 \mathrm{~h}(n=3, P<0.0005)$ (Fig. 3B).

We further tested whether the upregulation of Opn levels is mediated by the activation of LH-induced EGFR signaling, the most prominent mediator of the gonadotropin surge (Park et al. 2004). EGF itself is not upregulated by hCG stimulation in mouse ovaries. Therefore, in

(A)

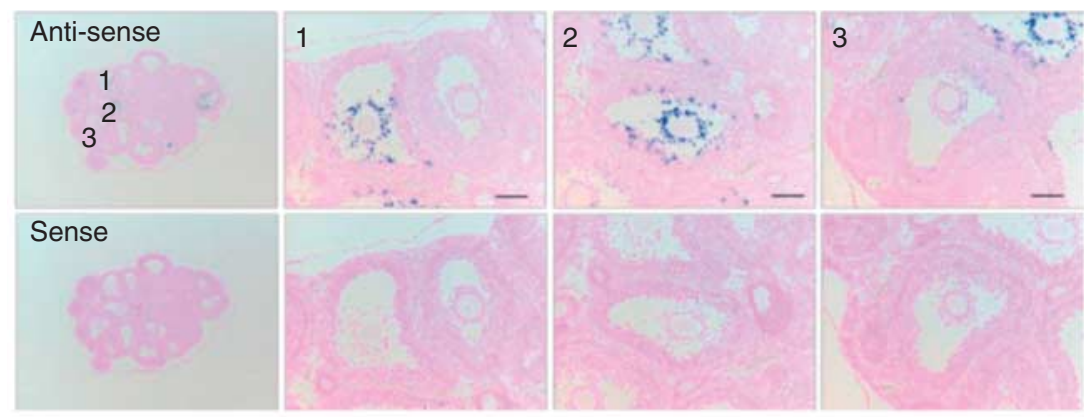

(B)

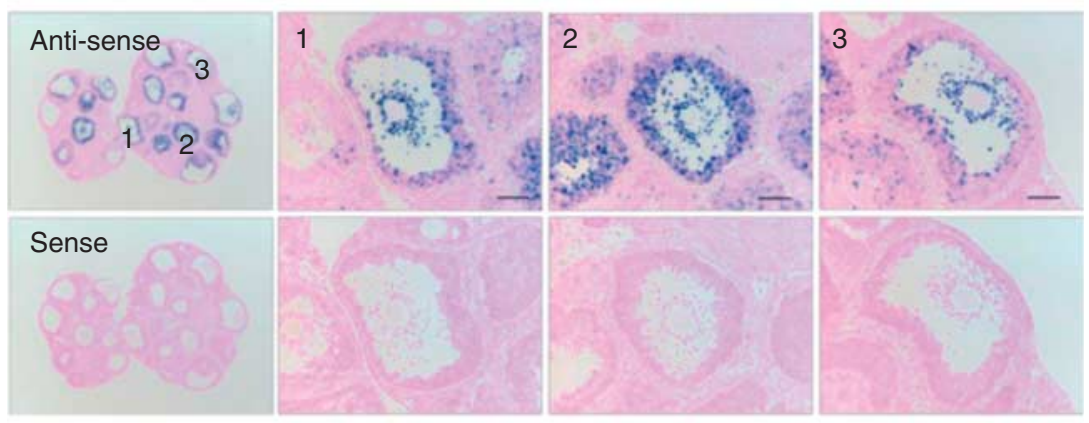

(C)

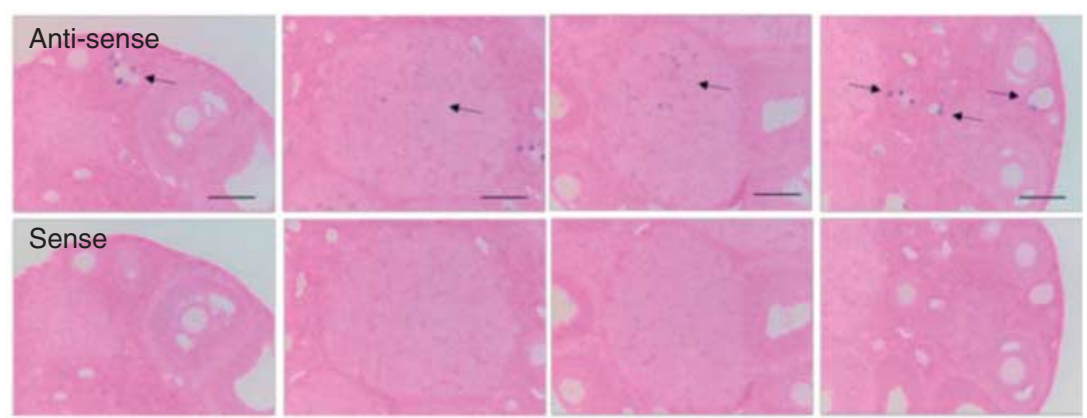

Figure 2

In situ hybridization (ISH) of Opn in gonadotropin-treated mouse ovaries. ISH was performed using both anti-sense and sense RNA probes for mouse Opn. Ovarian sections were obtained from mice pre-treated with PMSG, followed by hCG treatment for $10 \mathrm{~h}(\mathrm{~A})$ or $12 \mathrm{~h}(\mathrm{~B})$. Opn transcripts were detected in the cumulus cells of preovulatory follicles $10 \mathrm{~h}$ after hCG treatment (A). Opn transcripts were markedly expressed in GCs of preovulatory follicles $12 \mathrm{~h}$ after hCG treatment (B). In adult mice (16 weeks old), Opn transcripts (indicated by arrows) were sparsely distributed in the ovary (C). Scale bars $=100 \mu \mathrm{m}$. http://joe.endocrinology-journals.org DOI: $10.1530 / J O E-14-0203$
(C) 2015 Society for Endocrinology Printed in Great Britain 
(A)
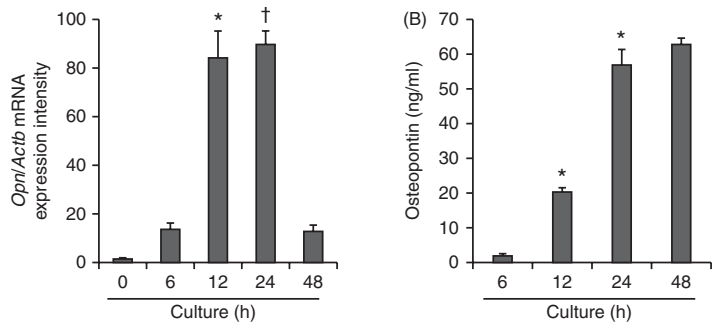

(C)

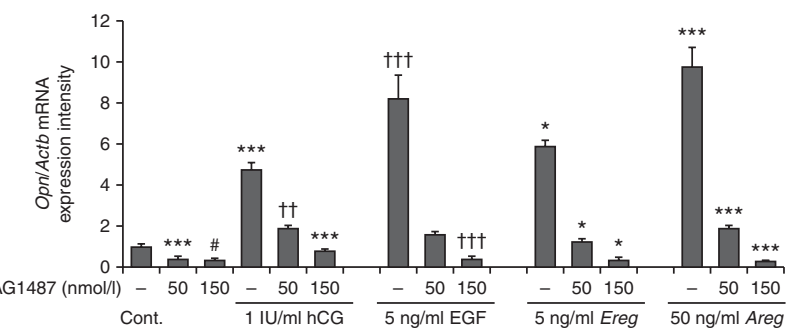

Figure 3

Expression and regulation of OPN in cultured GCs. Immature female mice were treated with PMSG, and GCs were isolated from preovulatory ovaries obtained $48 \mathrm{~h}$ later. GCs were cultured in the absence or presence of a luteinizing dose of hCG (1 IU/ml). (A) Real-time PCR analysis of Opn transcripts in cultured GCs. Changes in Opn expression are shown as fold increases relative to expression in GCs from PMSG-primed ovaries (cultured for $0 \mathrm{~h}$ ). $0 \mathrm{~h}$ versus $12 \mathrm{~h}$ : ${ }^{\star} P<0.0005$ and $0 \mathrm{~h}$ versus $24 \mathrm{~h}:{ }^{\dagger} P<0.00005$. (B) OPN levels measured in the supernatants of GC cultures by ELISA. Incubation with $1 \mathrm{IU} / \mathrm{ml}$ hCG caused a significant increase in OPN protein levels in the culture media of PMSG-primed GCs at 12 and $24 \mathrm{~h} .6 \mathrm{~h}$ versus $12 \mathrm{~h}$ : $* P<0.0005$ and $6 \mathrm{~h}$ versus $24 \mathrm{~h}$ : $* P<0.0005$. (C) Effect of stimulation and/or inhibition of EGFR on Opn expression in cultured GCs. GCs were cultured for $16 \mathrm{~h}$ with $1 \mathrm{IU} / \mathrm{ml} \mathrm{hCG,} 5 \mathrm{ng} / \mathrm{ml} \mathrm{EGF,} 5 \mathrm{ng} / \mathrm{ml}$ Ereg, or $50 \mathrm{ng} / \mathrm{ml}$ Areg. All molecules significantly stimulated Opn mRNA expression, compared with those in GCs cultured without any treatment (Cont.). hCG: ${ }^{* * *} P<0.005$; EGF: ${ }^{+\dagger+} P<0.05$; Ereg: ${ }^{*} P<0.0005$; and Areg: $* * * P<0.005$. Opn expression was significantly inhibited by the EGFR inhibitor AG1478 added at concentrations of 50 and $150 \mathrm{nmol} / \mathrm{l}$. Non-hormone-treated group: ${ }^{* *} P<0.005$ and ${ }^{\#} P<0.001$; hCG-treated group: ${ }^{+\dagger} P<0.01$ and $* * * P<0.005$; EGF-treated group: not significant and ${ }^{t+t} P<0.05$; Eregtreated group: ${ }^{*} P<0.0005$ and $* P<0.0005$; and Areg-treated group: $* * * P<0.005$ and $* * * P<0.005$. Changes in Opn expression levels are shown as fold increases relative to expression levels in control GCs (Cont.; cultured without any treatment for $16 \mathrm{~h}$ ). All data are presented as mean \pm s.E.M. for three independent experiments.

addition to hCG and EGF, we also induced stimulation of the EGF-like growth factors, Ereg and Areg, both of which are induced by hCG stimulation in mouse ovaries (Shimada et al. 2006). We cultured GCs for $16 \mathrm{~h}$ with $1 \mathrm{U} / \mathrm{ml} \mathrm{hCG}, 5 \mathrm{ng} / \mathrm{ml} \mathrm{EGF}, 5 \mathrm{ng} / \mathrm{ml}$ Ereg, or $50 \mathrm{ng} / \mathrm{ml}$ Areg in the presence or absence of AG1478 (50 or $150 \mathrm{nmol} / \mathrm{l}$ ), which selectively blocks the activation of the EGFR tyrosine kinase. All molecules significantly stimulated Opn mRNA expression, compared with those in GCs cultured without any treatment (Cont.) (hCG: $n=3$, $P<0.005$; EGF: $n=3, P<0.05$; Ereg: $n=3, P<0.0005$; and Areg: $n=3, P<0.005$ ) (Fig. 3C). Furthermore, expression was significantly inhibited by the EGFR inhibitor AG1478 in a dose-dependent manner (50 nmol/l AG1478: $n=3$, $P<0.005 ; 150 \mathrm{nmol} / 1$ AG1478: $n=3, P<0.001 ;$ hCG + $50 \mathrm{nmol} / 1$ AG1478: $n=3, P<0.01 ; \mathrm{hCG}+150 \mathrm{nmol} / 1$ AG1478: $n=3, P<0.005$; EGF $+150 \mathrm{nmol} / 1$ AG1478: $n=3$, $P<0.05$; Ereg $+50 \mathrm{nmol} / \mathrm{l}$ AG1478: $n=3, P<0.0005$; Ereg+ $150 \mathrm{nmol} / \mathrm{l}$ AG1478: $n=3, P<0.0005 ;$ Areg $+50 \mathrm{nmol} / \mathrm{l}$ AG1478: $n=3, P<0.005$; and Areg $+150 \mathrm{nmol} / 1$ AG1478: $n=3, P<0.005)$. These results indicated that up-regulation of Opn expression is mediated by EGFR signaling, which is triggered by an LH surge.

\section{Effect of OPN treatment on progesterone synthesis in cultured GCs}

Because Opn expression was localized to the early luteinizing GCs, OPN-mediated signaling is probably involved in corpus luteum formation and function. Using the GC culture system, we evaluated the progesterone concentrations in the culture media by ELISA. GCs were collected from PMSG-primed mice and incubated for 12 or $24 \mathrm{~h}$ in culture media containing $1 \mathrm{U} / \mathrm{ml}$ hCG with or without $0.2 \mu \mathrm{mol} / \mathrm{l} \mathrm{OPN}$. OPN treatment led to a significant increase in progesterone concentration in the culture medium after $24 \mathrm{~h}(n=4 ; P<0.05$; Fig. 4A). We also evaluated the effect of OPN treatment on the expression of molecules related to progesterone synthesis. OPN treatment led to a significant increase in Star $(n=4 ; 24 \mathrm{~h}, P<0.005$; Fig. 4B), p450scc ( $n=4 ; 12 \mathrm{~h}, P<0.05$ and $24 \mathrm{~h}, P<0.05$; Fig. $4 \mathrm{C}$ ), and Hsd $3 b$ $(n=4 ; 12 \mathrm{~h}, P<0.0005$ and $24 \mathrm{~h}, P<0.005$; Fig. $4 \mathrm{D})$ transcripts. These results indicated that OPN is involved in progesterone synthesis by promoting the expression of molecules related to progesterone synthesis.

\section{Effect of OPN treatment on the signaling pathway to enhance Vegf expression in cultured GCs}

VEGF is a prominent angiogenic factor that exists in the ovary during follicular development (Kaczmarek et al. 2005); therefore, we evaluated the effect of OPN treatment on expression of Vegf using the GC culture system. We confirmed that OPN treatment significantly increased Vegf transcripts (data not shown). Recently, it has been found that OPN reportedly induces Vegf expression through the activation of PI3K/AKT and ERK1/2 in endothelial cells (Dai et al. 2009). Therefore, we tested the effects of blocking these pathways on the promotion of expression of Vegf by OPN in GCs. GCs were pretreated for $1 \mathrm{~h}$ with LY294002 (50 $\mu \mathrm{mol} / \mathrm{l})$, a PI3K inhibitor, and/or PD980592 $(100 \mu \mathrm{mol} / \mathrm{l})$, an ERK inhibitor, and cells were incubated for $20 \mathrm{~h}$ with $0.2 \mu \mathrm{mol} / \mathrm{l} \mathrm{OPN}$ in the culture medium

Published by Bioscientifica Ltd. 

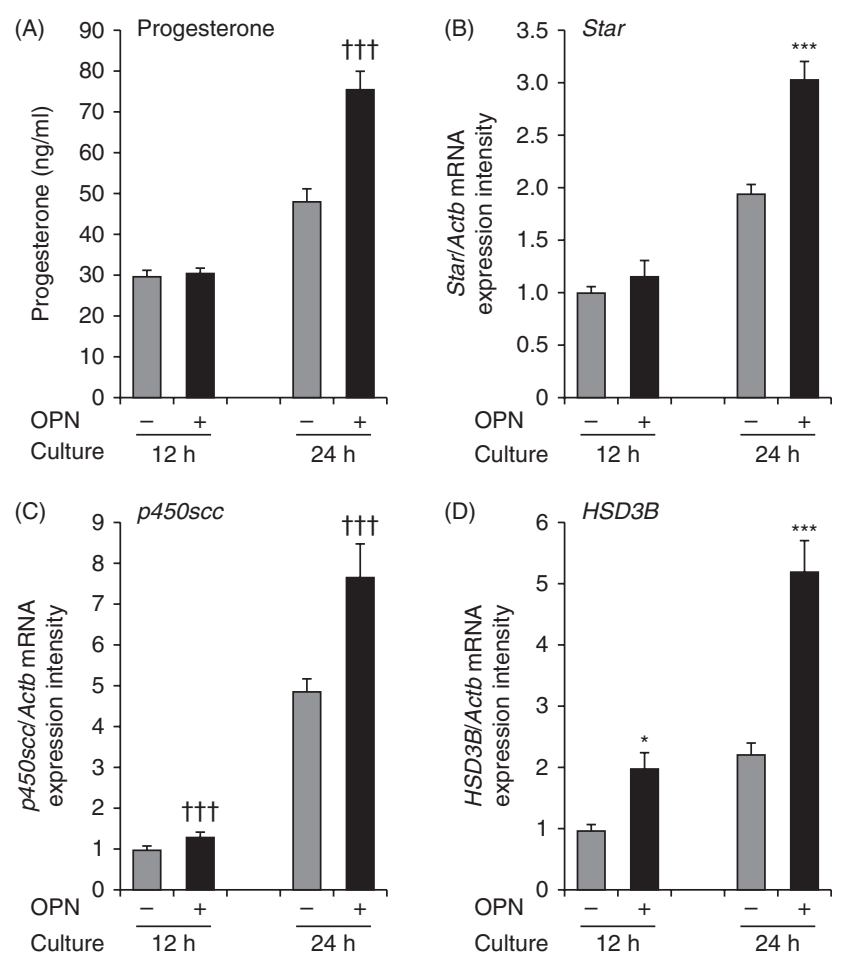

\section{Figure 4}

Effect of OPN treatment on progesterone synthesis in cultured GCs. GCs were collected from PMSG-primed mice and incubated in culture media containing $1 \mathrm{IU} / \mathrm{ml} \mathrm{hCG}$ with or without $0.2 \mu \mathrm{mol} / / \mathrm{OPN}$ for 12 or $24 \mathrm{~h}$.

(A) OPN treatment significantly increased progesterone concentration in the culture medium at $24 \mathrm{~h}, n=3 ;{ }^{t+\dagger} P<0.05$. (B, C and D) OPN treatment significantly increased the transcription of molecules associated with progesterone synthesis, $n=4$; (B) Star $24 \mathrm{~h}$ : $* * *<0.005$; (C) $p 450$ scc $12 \mathrm{~h}$ : ${ }^{+t+} P<0.05$ and $24 \mathrm{~h}:{ }^{t+\dagger} P<0.05$; and (D) HSD $3 B 12 \mathrm{~h}:{ }^{*} P<0.0005$ and $24 \mathrm{~h}:$ $* * * P<0.005$. Changes in transcripts levels of each molecule are shown as fold increases relative to levels in GCs cultured without OPN for $12 \mathrm{~h}$. All data are presented as mean \pm S.E.M. for three or four independent experiments.

containing hCG. OPN treatment significantly increased $V e g f$ transcripts $(n=3, P<0.005)$, and Vegf expression was inhibited significantly by incubation with LY294002 $(n=3$; LY294002: $P<0.005$ and LY294002+PD80592: $P<0.0005$ ), but not by PD80592 alone (Fig. 5A). These results indicated that OPN primarily enhances expression of Vegf through the PI3K/AKT pathway, but not through ERK. Next, we confirmed whether OPN stimulation of GCs promotes the activation of AKT, a downstream PI3K signaling molecule. GCs from PMSG-primed immature mice were pre-treated with $1 \mathrm{IU} / \mathrm{ml}$ hCG for $12 \mathrm{~h}$ and incubated with or without $0.2 \mu \mathrm{mol} / \mathrm{l}$ OPN for $15 \mathrm{~min}$. GCs were collected, and cell lysates were subjected to western blotting analysis for detection of AKT phosphorylation using the following AKT-specific antibodies: rabbit anti-AKT, rabbit anti-p-AKT (Ser ${ }^{473}$ ), and rabbit anti-p-AKT
$\left(\mathrm{Thr}^{308}\right)$. Treatment with OPN for 15 min significantly stimulated the phosphorylation of AKT at its regulatory residues $\operatorname{Thr}^{308}(n=3, P<0.005)$ and $\operatorname{Ser}^{473}(n=3, P<0.05)$ (Fig. 5B).

\section{Discussion}

The periovulatory period is characterized by a surge of gonadotropins that brings about dramatic functional and structural changes in the ovary, leading to oocyte maturation, follicle rupture, and corpus luteum formation. Several studies have shown that the gonadotropin surge induces rapid but transient expression of specific genes associated with this process (Richards et al. 1998, Tsafriri \& Reich 1999). On the basis of the results obtained using the PCR array and real-time RT-PCR analyses of mouse ovarian gene expression during the periovulatory period, we found a marked increase in Opn levels. In vitro analyses using cultured GCs also provided evidence of OPN protein secretion in response to hCG treatment.

Because Opn expression, stimulated by gonadotropin, was clearly localized on ovarian mural GCs as observed by ISH, we focused on expression of Opn in the mural GCs during the periovulatory period. According to the results from the immature mouse ovarian stimulation model, there was a considerable time lag $(16 \mathrm{~h})$ before levels of Opn reached a peak value after hCG injection. Therefore, we speculated that molecular signaling might mediate the gonadotropin surge to promote expression of Opn . Recently, results from several studies have indicated that EGF-like growth factors (e.g. amphiregulin and epiregulin) are prominent mediators of LH action in the ovulatory follicle (Park et al. 2004). Furthermore, up-regulation of the expression of Opn by EGF has been reported for several cultured cell types, including breast cancer, colon cancer, rat kidney epithelial, HL60, and HepG2 cells (Atkins et al. 1997, Malyankar et al. 1997, Zhang et al. 2003). We investigated whether EGFR signaling is also involved in the promotion of the expression of Opn in mouse GCs. On the basis of in vitro analyses using cultured GCs, EGF and EGF-like growth factors stimulated expression of $O p n$, while an EGFR antagonist completely inhibited the effects of hCG on the expression of Opn. These findings indicate that EGFR signaling is a prominent pathway for mediating the LH surge, thus enhancing the expression of Opn. Because EGF-like growth factors are involved in several ovarian physiological processes, including ovulation, steroidogenesis, oocyte maturation, and cumulus expansion (Hsieh et al. 2009), it is interesting to consider that these physiological processes may be

Published by Bioscientifica Ltd 


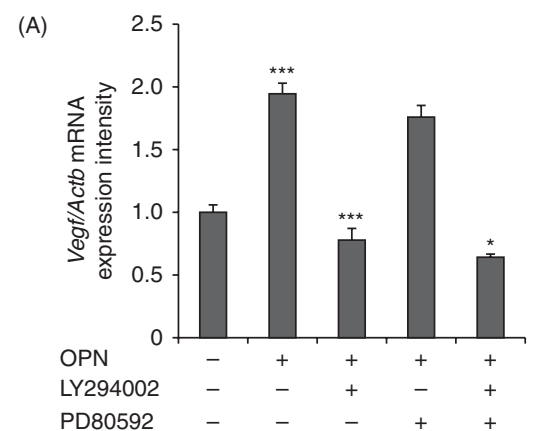

(B)
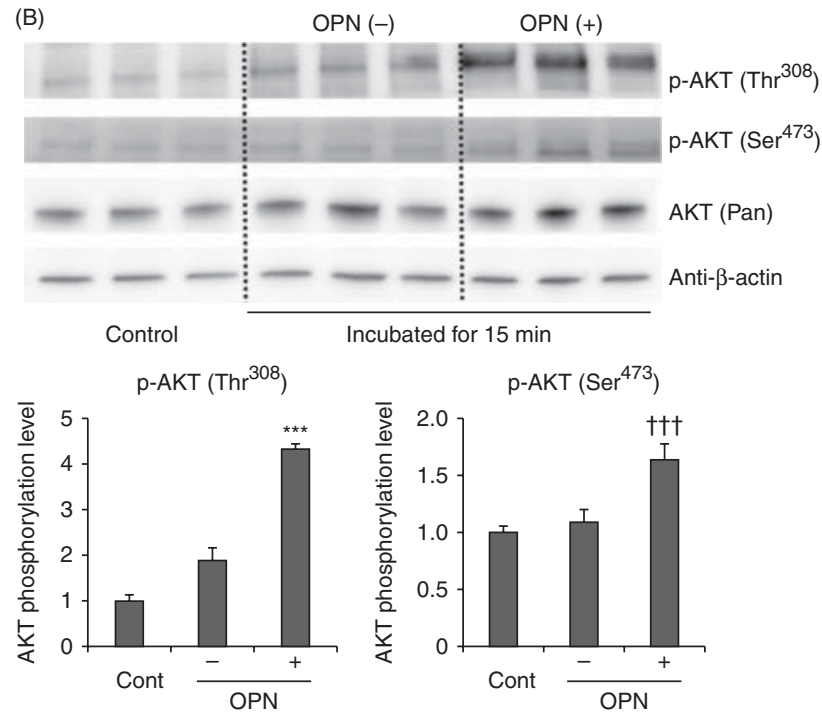

\section{Figure 5}

Effect of treatment with OPN on signaling pathway enhancing expression of Vegf expression in cultured GCs. (A) GCs were pretreated for $1 \mathrm{~h}$ with LY294002, a PI3K inhibitor (50 $\mu \mathrm{mol} / \mathrm{l})$, and/or PD980592, an ERK inhibitor $(100 \mu \mathrm{mol} / \mathrm{l})$, and then GCs were incubated for $20 \mathrm{~h}$ with $0.2 \mu \mathrm{mol} / \mathrm{l}$ OPN in culture media containing $1.0 \mathrm{lU} / \mathrm{ml} \mathrm{hCG}$. Incubation with OPN significantly increased Vegf transcripts. $* * * P<0.005$. The increase was inhibited significantly by incubation with LY294002, but not by PD80592 alone. LY294002: $* * * P<0.005$ and LY294002+PD80592: $* P<0.0005$. Changes in Vegf levels are shown as fold increases relative to levels in GCs cultured without OPN, LY294002, or PD80592. (B) Detection of AKT phosphorylation in OPN-treated GCs. GCs from PMSG-primed immature mice were pretreated with $1 \mathrm{IU} / \mathrm{ml} \mathrm{hCG}$ for $12 \mathrm{~h}$ and incubated with or without $0.2 \mu \mathrm{mol} / \mathrm{l}$ OPN for $15 \mathrm{~min}$. GCs were collected, and cell lysates were subjected to western blotting to detect AKT phosphorylation using the following AKT-specific antibodies: rabbit anti-AKT (Pan), rabbit anti-phospho-AKT (anti-p-AKT Ser ${ }^{473}$ ), and rabbit anti-p-AKT $\left(\mathrm{Thr}^{308}\right)$. Densitometric analysis of p-AKT levels normalized to total AKT levels. Thr ${ }^{308}: * \star * P<0.005$ and Ser ${ }^{473}:{ }^{1+\dagger} P<0.05$. Changes in $\mathrm{p}$-AKT levels are shown as fold increases relative to those in controls (GCs before OPN treatment). All data are presented as mean \pm s.E.M. for three independent experiments.

partially mediated by OPN signaling. The up-regulation of Opn expression during the early-corpus luteum phase and the effect of OPN on GCs promoting progesterone synthesis strongly support the enhancement of corpus luteum function by OPN during this period. As levels of
OPN also increased with hCG treatment, similar to Opn transcripts, it is likely that locally secreted OPN from GCs can leak into blood circulation. Consequently, it would be fascinating to evaluate plasma OPN as a potential biomarker in infertile patients in a future study.

In the ovaries, there is intense angiogenesis throughout follicular development, allowing adequate nutritional and hormonal supply for ovarian follicular growth, oocyte development, ovulation, and subsequent corpus luteum formation. Several pro-angiogenic factors exist in the ovary during follicular development, such as VEGF, fibroblast growth factor 2, angiotensin 2, insulin-like growth factor 1, EGF, angiopoietin, and endothelin 1 (Bruno et al. 2009). OPN reportedly enhances the expression of Vegf and induces angiogenesis in endothelial cells (Dai et al. 2009). In this study, we showed that OPN treatment in the GC culture system promotes the expression of Vegf, which encodes a prominent angiogenic factor in the early luteinizing period. We also showed that treatment with a PI3K inhibitor in the GC culture system significantly suppresses the promotion of Vegf expression, and that OPN treatment stimulates the phosphorylation of AKT, a downstream PI3K signaling molecule. Taking these results together, OPN is considered to serve as a proangiogenic factor in the ovary during the early-luteal phase by promoting expression of Vegf through PI3K/AKT signaling, which enhances corpus luteum formation by promoting vascular formation.

According to the results from ISH experiments, a gonadotropin surge primarily stimulates $O p n$ expression in cumulus cells in advance of mural GCs, indicating that OPN is also implicated in some physiological roles in cumulus-oocyte complexes. Interestingly, there are some similarities between OPN and hyaluronic acid (HA), because both are categorized as extracellular matrix components, and both are present on the surfaces of cumulus cells in response to a gonadotropin surge. Furthermore, OPN and HA can be degraded into smaller biologically active fragments by specific enzymes and bind to the same cell-surface receptor, CD44 antigen. As HA is known to play crucial roles in cumulus cell expansion, oocyte maturation, and further embryonic development (Marei et al. 2012), it can be speculated that these physiological processes are also regulated by OPN. In vitro oocyte culture experiments to assess the effects of OPN on oocyte nuclear maturation rates, embryo development to blastocyst stage, and blastocyst quality may provide additional insights into the role of OPN. This new understanding might allow future use of OPN during follicle culture and in vitro oocyte maturation in clinical practice.

Published by Bioscientifica Ltd. 
Along with the CD44 antigen, OPN binds several different integrin receptors, including $\alpha \mathrm{v} \beta 1, \alpha v \beta 3, \alpha v \beta 5$, $\alpha 4 \beta 1$, and $\alpha 9 \beta 1$, through its conserved cell-binding arginine-glycine-aspartic acid domain (Hu et al. 1995, Liaw et al. 1995a,b, Smith et al. 1996, Bayless et al. 1998). Interestingly, binding of OPN to these receptors has distinct functional consequences (Tuck et al. 2000). To our knowledge, this is the first study to demonstrate molecular evidence that OPN transcriptionally enhances progesterone synthesis and follicular angiogenesis. As OPN is a multifunctional molecule, it might also be involved in other physiological processes such as tissue remodeling after ovarian injury caused by ovulation and/or survival of early-luteal cells. Further investigation, specifically a blocking assay using cell-surface-receptor-specific blockers, might provide an in-depth understanding of OPN function in the ovary, especially ligand-receptor interactions and distinct biological functions.

In a previous investigation using OPN-knockout mice, a specific ovarian phenotype was not mentioned, and the mice were reportedly fertile (Liaw et al. 1995a,b). Therefore, up-regulaton of $O p n$ in the periovulatory phase appears not to be essential for the maintenance of ovarian function. During OPN deficiency, other molecules induced by the gonadotropin surge may be acting in a compensatory manner during the periovulatory period. Accordingly, OPN is considered to be a contributor to maintaining proper periovulatory ovarian function. This contribution is important because stable ovarian physiology is achieved by multi-component molecular processes, which is essential for maintaining female reproductive capacity and for species preservation.

In conclusion, Opn expression is markedly upregulated in mouse ovarian GCs in response to a gonadotropin surge through EGFR signaling, which enhances progesterone synthesis and expression of Vegf during the early-luteal phase.

\section{Supplementary data}

This is linked to the online version of the paper at http://dx.doi.org/10.1530/ JOE-14-0203.

\section{Declaration of interest}

The authors declare that there is no conflict of interest that could be perceived as prejudicing the impartiality of the research reported.

\section{Funding}

This research did not receive any specific grant from any funding agency in the public, commercial or not-for-profit sector.

\section{References}

Applied Biosystems 1997 Relative quantitation of gene expression. In ABI PRISM 7700 Sequence Detection System User Bulletin 2. Foster City, CA, USA: Applied Biosystems.

Atkins KB, Simpson RU \& Somerman MJ 1997 Stimulation of osteopontin mRNA expression in HL-60 cells is independent of differentiation. Archives of Biochemistry and Biophysics 343 157-163. (doi:10.1006/abbi. 1997.0151)

Bayless KJ, Meininger GA, Scholtz JM \& Davis GE 1998 Osteopontin is a ligand for the $\alpha_{4} \beta_{1}$ integrin. Journal of Cell Science 111 1165-1174.

Bobe J \& Goetz FW 2001 A novel osteopontin-like protein is expressed in the trout ovary during ovulation. FEBS Letters 489 119-124. (doi:10.1016/S0014-5793(01)02090-7)

Brown LF, Berse B, Van de Water L, Papadopoulos-Sergiou A, Perruzzi CA, Manseau EJ, Dvorak HF \& Senger DR 1992 Expression and distribution of osteopontin in human tissues: widespread association with luminal epithelial surfaces. Molecular Biology of the Cell 3 1169-1180. (doi:10.1091/mbc.3.10.1169)

Bruno JB, Matos MHT, Chaves RN, Celestino JJH, Saraiva MVA, Lima-Verde IB, Araújo VR \& Figueiredo JR 2009 Angiogenic factors and ovarian follicle development. Animal Reproduction 6 371-379.

Brunswig-Spickenheier B \& Mukhopadhyay AK 2003 Expression of osteopontin (OPN) mRNA in bovine ovarian follicles and corpora lutea. Reproduction in Domestic Animals 38 175-181. (doi:10.1046/j.14390531.2003.00413.x)

Butler WT 1989 The nature and significance of osteopontin. Connective Tissue Research 23 123-136. (doi:10.3109/03008208909002412)

Christenson LK \& Stouffer RL 1997 Follicle-stimulating hormone and luteinizing hormone/chorionic gonadotropin stimulation of vascular endothelial growth factor production by macaques granulosa cells from pre- and periovulatory follicles. Journal of Clinical Endocrinology and Metabolism 82 2135-2142. (doi:10.1210/jcem.82.7.4169)

Corjay MH, Diamond SM, Schlingmann KL, Gibbs SK, Stoltenborg JK \& Racanelli AL $1999 \alpha \mathrm{v} \beta 3, \alpha \mathrm{v} \beta 5$, and osteopontin are coordinately upregulated at early time points in a rabbit model of neointima formation. Journal of Cellular Biochemistry 75 492-504. (doi:10.1002/ (SICI)1097-4644(19991201)75:3 <492::AID-JCB13>3.0.CO;2-Z)

Dai J, Peng L, Fan K, Wang H, Wei R, Ji G, Cai J, Lu B, Li B, Zhang D et al. 2009 Osteopontin induces angiogenesis through activation of PI3K/AKT and ERK1/2 in endothelial cells. Oncogene 28 3412-3422. (doi:10.1038/onc.2009.189)

Denhardt DT \& Guo X 1993 Osteopontin: a protein with diverse functions. FASEB Journal 7 1475-1482.

Gabler C, Chapman DA \& Killian GJ 2003 Expression and presence of osteopontin and integrins in the bovine oviduct during the oestrous cycle. Reproduction 126 721-729. (doi:10.1530/rep.0.1260721)

Giachelli C, Bae N, Lombardi D, Majesky M \& Schwartz S 1991 Molecular cloning and characterization of $2 \mathrm{~B} 7$, a rat mRNA which distinguishes smooth muscle cell phenotypes in vitro and is identical to osteopontin (secreted phosphoprotein I, 2aR). Biochemical and Biophysical Research Communications 177 867-873. (doi:10.1016/0006-291X(91)91870-I)

Giachelli CM, Liaw L, Murry CE, Schwartz SM \& Almeida M 1995 Osteopontin expression in cardiovascular diseases. Annals of the New York Academy of Sciences 760 109-126. (doi:10.1111/j.1749-6632.1995. tb44624.x)

Hsieh M, Zamah AM \& Conti M 2009 Epidermal growth factor-like growth factors in the follicular fluid: role in oocyte development and maturation. Seminars in Reproductive Medicine 27 52-61. (doi:10.1055/ s-0028-1108010)

Hu DD, Lin EC, Kovach NL, Hoyer JR \& Smith JW 1995 A biochemical characterization of the binding of osteopontin to integrins $\alpha_{\mathrm{v}} \beta_{1}$ and $\alpha_{v} \beta_{5}$. Journal of Biological Chemistry 270 26232-26238. (doi:10.1074/ jbc.270.44.26232) 
Ingber DE 1992 Extracellular matrix as a solid-state regulator in angiogenesis: identification of new targets for anti-cancer therapy. Seminars in Cancer Biology 3 57-63.

Johnson GA, Spencer TE, Burghardt RC \& Bazer FW 1999 Ovine osteopontin: I. Cloning and expression of messenger ribonucleic acid in the uterus during the periimplantation period. Biology of Reproduction 61 884-891. (doi:10.1095/biolreprod61.4.884)

Kaczmarek MM, Schams D \& Ziecik AJ 2005 Role of vascular endothelial growth factor in ovarian physiology - an overview. Reproductive Biology 5 111-136. (doi:10.1016/S0015-0282(00)00670-1)

Kuwabara Y, Katayama A, Igarashi T, Tomiyama R, Piao H, Kaneko R, Abe T, Mine K, Akira S, Orimo H et al. 2012 Rapid and transient upregulation of CCL11 (eotaxin-1) in mouse ovary during terminal stages of follicular development. American Journal of Reproductive Immunology 67 358-368. (doi:10.1111/j.1600-0897.2011.01100.x)

Liaw L, Lindner V, Schwartz SM, Chambers AF \& Giachelli CM 1995a Osteopontin and $\beta_{3}$ integrin are coordinately expressed in regenerating endothelium in vivo and stimulate Arg-Gly-Asp-dependent endothelial migration in vitro. Circulation Research 77 665-672. (doi:10.1161/ 01.RES.77.4.665)

Liaw L, Skinner MP, Raines EW, Ross R, Cheresh DA, Schwartz SM \& Giachelli CM 1995b The adhesive and migratory effects of osteopontin are mediated via distinct cell surface integrins. Role of $\alpha_{\mathrm{v}} \beta_{3}$ in smooth muscle cell migration to osteopontin in vitro. Journal of Clinical Investigation 95 713-724. (doi:10.1172/JCI117718)

Malyankar UM, Almeida M, Johnson RJ, Pichler RH \& Giachelli CM 1997 Osteopontin regulation in cultured rat renal epithelial cells. Kidney International 51 1766-1773. (doi:10.1038/ki.1997.243)

Marei WF, Ghafari F \& Fouladi-Nashta AA 2012 Role of hyaluronic acid in maturation and further early embryo development of bovine oocytes. Theriogenology 78 670-677. (doi:10.1016/j.theriogenology. 2012.03.013)

McRae RS, Johnston HM, Mihm M \& O'Shaughnessy PJ 2005 Changes in mouse granulosa cell gene expression during early luteinization. Endocrinology 146 309-317. (doi:10.1210/en.2004-0999)

Park JY, Su YQ, Ariga M, Law E, Jin SL \& Conti M 2004 EGF-like growth factors as mediators of $\mathrm{LH}$ action in the ovulatory follicle. Science $\mathbf{3 0 3}$ 682-684. (doi:10.1126/science.1092463)
Poole DH, Ndiaye K \& Pate JL 2013 Expression and regulation of secreted phosphoprotein 1 in the bovine corpus luteum and effects on T cell lymphocyte chemotaxis. Reproduction 146 527-537. (doi:10.1530/REP13-0190)

Richards JS 1994 Hormonal control of gene expression in the ovary. Endocrine Reviews 15 725-751. (doi:10.1210/edrv-15-6-725)

Richards JS, Russell DL, Robker RL, Dajee M \& Alliston TN 1998 Molecular mechanisms of ovulation and luteinization. Molecular and Cellular Endocrinology 145 47-54. (doi:10.1016/S0303-7207(98)00168-3)

Shimada M, Hernandez-Gonzalez I, Gonzalez-Robayna I \& Richards JS 2006 Paracrine and autocrine regulation of epidermal growth factor-like factors in cumulus oocyte complexes and granulosa cells: key roles for prostaglandin synthase 2 and progesterone receptor. Molecular Endocrinology 20 1352-1365. (doi:10.1210/me.2005-0504)

Smith LL, Cheung HK, Ling LE, Chen J, Sheppard D, Pytela R \& Giachelli CM 1996 Osteopontin N-terminal domain contains a cryptic adhesive sequence recognized by $\alpha_{9} \beta_{1}$ integrin. Journal of Biological Chemistry 271 28485-28491. (doi:10.1074/jbc.271.45. 28485)

Sodek J, Ganss B \& McKee MD 2000 Osteopontin. Critical Reviews in Oral Biology and Medicine 11 279-303. (doi:10.1177/1045441100011 0030101)

Tsafriri A \& Reich R 1999 Molecular aspects of mammalian ovulation. Experimental and Clinical Endocrinology \& Diabetes 107 1-11. (doi:10.1055/s-0029-1212066)

Tuck AB, Elliott BE, Hota C, Tremblay E \& Chambers AF 2000 Osteopontininduced, integrin-dependent migration of human mammary epithelial cells involves activation of the hepatocyte growth factor receptor (Met). Journal of Cellular Biochemistry 78 465-475. (doi:10.1002/10974644(20000901)78:3<465::AID-JCB11>3.0.CO;2-C)

Yue TL, McKenna PJ, Ohlstein EH, Farach-Carson MC, Butler WT, Johanson K, McDevitt P, Feuerstein GZ \& Stadel JM 1994 Osteopontin-stimulated vascular smooth muscle cell migration is mediated by $\beta_{3}$ integrin. Experimental Cell Research 214 459-464. (doi:10.1006/excr.1994.1282)

Zhang G, He B \& Weber GF 2003 Growth factor signaling induces metastasis genes in transformed cells: molecular connection between Akt kinase and osteopontin in breast cancer. Molecular and Cellular Biology 23 6507-6519. (doi:10.1128/MCB.23.18.6507-6519.2003)

Received in final form 26 October 2014

Accepted 28 October 2014

Accepted Preprint published online 28 October 2014 http://joe.endocrinology-journals.org DOI: 10.1530/JOE-14-0203
(C) 2015 Society for Endocrinology Printed in Great Britain 